\title{
А. Б. Лихачева
}

Институт языков и культур Балтийского региона Вильнюсского университета, Вильнюс

\section{ЯЗЫКОВАЯ ПОВСЕДНЕВНОСТЬ ВИЛЬНЮСА \\ С ПОЗИЦИЙ АКСИОЛОГИЧЕСКОЙ СОЦИОЛИНГВИСТИКИ}

\section{1. Вводные замечания}

Социолингвистические исследования восприятия языков, используемых в том или ином обществе, свидетельствуют о социальной обусловленности отношения к языку и к его носителям (см. [Вахтин, Головко 2004]). Причем в этнически неоднородном государстве важны как установки титульной нации относительно миноритарной этнической группы и ее языка, так и прагматические и эмоциональные оценки своего языка жителями, для которых этот язык является единственным родным или одним из родных языков [Лихачева 2015; Лихачева 2014a; Lichačiova, Markova 2014]. Положительное восприятие и оценка родного языка (а с ним — и самовосприятие) его носителями, живущими в иноязычных условиях, помимо прочего, могут служить одним из индикаторов этнолингвистической витальности языковой группы (см. [Allard, Landry 1992: 171-196]).

Описание языковой ситуации и оценки языков, сосуществующих в едином городском пространстве, целесообразно осуществлять с привлечением не только экспертных мнений, но и «гласа народа», поскольку народная точка зрения, взятая сама по себе, уже есть часть социолингвистической ситуации [Брайт 1975: 37], она может являться показателем как комфорта, так и потенциального языкового конфликта субъектов социальной интеракции.

В этой статье приводятся высказывания бывших и теперешних жителей Вильнюса о том, что они думают о своем языковом существовании. Анализируются мнения ученых и писателей, фрагменты 
из социолингвистических интервью, записанных в ходе различных исследований, интернет-заметки и комментарии к ним, связанные с сегодняшней языковой ситуацией в Вильнюсе.

В несколько измененном виде по сравнению с определением «народной лингвистики», изучающей то, что люди «думают о своем языковом поведении и языковом поведении других», приведенном в [Брайт 1975], представленную в этой статье область исследований можно назвать аксиологической социолингвистикой, для которой важна оценочная сторона использования разных языков в повседневной жизни общества.

С аксиологическим, или оценочным, планом существования языка в обществе связаны такие явления, как социальный престиж языка, его востребованность в системе образования, присутствие в культурном и информационном пространстве [Bourdieu 1991]. Это особенно существенно для миноритарных языков, которые их носителями и особенно носителями титульного языка могут восприниматься как нормальные, естественные или, наоборот, как чужеродные и нежелательные компоненты обыденной языковой жизни социума.

\section{2. Этническое и языковое разнообразие Вильнюса в динамическом аспекте}

В Вильнюсе в 1926 г. (город тогда входил в состав Польши) родился и до отроческого возраста жил Уриель Вайнрайх (Uriel Weinreich), ставший впоследствии известным американским лингвистом. В 1940 г. семья Вайнрайхов эмигрировала в США. В научном мире Уриель Вайнрайх известен как автор первого университетского учебника идиша для англоязычных учащихся (1949), а главное как теоретик контактной лингвистики, языковой интерференции и один из основателей социолингвистики. Можно предположить, что профессиональные интересы лингвиста сформировались не без влияния его детского опыта проживания в многоязычном городе.

Русский философ и литературовед Михаил Бахтин подростковые годы (с 1905-го по 1911-й) вместе с семьей также провел в Вильнюсе, в то время входившем в состав Российской империи. Американские биографы М. Бахтина связывают его жизнь в городе, слывшем в начале XX в. многоязычным и многокультурным, с идеей гетероглоссии [Clark and Holquist 1984], или, по Бахтину, 
разноречья, в отличие от одноязычия и многоязычия: «Гетероглоссия, или скрещивание различных языков, культур и сословий для Бахтина было идеальным состоянием, которое обеспечивает постоянную интеллектуальную и культурную революцию, защищающую то или иное общество от „единственного верного языка“ или „официального языка“", от застоя и оцепенелости мысли». Так о влиянии города на профессиональные воззрения М. Бахтина пишет в своей книге «Вильнюс. Город в Европе» литовский поэт и литературовед Томас Венцлова, профессор славистики Йельского университета [Венцлова 2012: 18].

«Во времена Бахтина - и до них, и после, - продолжает Венцлова, — в Вильнюсе проживало множество разных народов (в советское время, несмотря на тенденцию сливать некоторые национальности с русской, перепись зафиксировала их восемьдесят). Конечно, народы - это “воображаемые общины”: их состав и само их понятие постоянно меняются, Вильнюс - одна из лучших лабораторий, где можно наблюдать и осмыслять этот процесс. Семь национальных групп (литовцы, белорусы (иначе - русины, гуды), поляки, русские, евреи, татары, караимы. - А. Л.), иногда не слишком больших, но поселившихся в городе со времен Средневековья, принято называть коренными. 〈...〉Ни одна из этих наций не может утверждать, что Вильнюс принадлежит только ей. Неповторимый, почти фантастический сплав языков, национальных традиций и религий в этом городе игнорирует любые политические границы. Это всегда бросалось в глаза приезжим, а местные жители попросту думали, что по-другому и быть не может» [Венцлова 2012: 19, 18].

Разумеется, языковое разнообразие Вильнюса с годами менялось (см. табл. 1 - по материалам [Stravinskienė 2013: 21], [Vilniaus tautos]), что связано с общественными и политическими трансформациями и - как следствие - с естественными и насильственными переменами в этническом составе жителей. Первая всеобщая перепись населения Российской империи отразила демографическую картину Вильнюса 1897 г., данные с 1920 по 1939 г. - польский период существования Вильнюса, позже, до начала 90-х годов прошлого века - этнический состав Вильнюса как столицы союзной республики в составе СССР. Данные двух последних переписей населения относятся уже к периоду независимой Литвы. 
Таблица 1. Изменения этнического состава жителей Вильнюса с 1897 по 2011 г.; в \%

\begin{tabular}{|c|c|c|c|c|c|c|}
\hline Годы & Литовцы & Поляки & Русские & Белорусы & Евреи & Др. \\
\hline 1897 & 2,1 & 31,0 & 20,0 & 4,2 & 40,0 & 2,7 \\
\hline 1916 & 2,1 & 53,7 & 1,6 & 0,4 & 41,5 & 0,7 \\
\hline 1920 & 2,3 & 56,1 & 3,1 & 1,4 & 36,2 & 0,9 \\
\hline 1923 & 0,8 & 60,1 & 2,8 & 2,3 & 33,5 & 5,0 \\
\hline 1928 & 1,3 & 55,6 & 5,9 & 0,5 & 35,8 & 0,9 \\
\hline 1931 & 0,8 & 65,9 & 3,8 & 0,9 & 28,0 & 0,6 \\
\hline 1939 & 0,7 & 66,0 & 3,7 & 0,8 & 27,5 & 1,3 \\
\hline 1959 & 33,6 & 20,0 & 29,5 & 6,5 & 7,0 & 3,4 \\
\hline 1989 & 50,5 & 18,8 & 20,2 & 5,3 & 1,6 & 3,6 \\
\hline 2001 & 57,8 & 18,7 & 14,0 & 4,0 & 0,5 & 5,0 \\
\hline 2011 & 63,2 & 16,5 & 12,0 & 3,5 & - & 4,8 \\
\hline
\end{tabular}

\section{3. Языки и этнические меньшинства Литвы}

Сегодня Литва - страна в целом мононациональная: 86,27\% ее населения составляет титульная нация (см. [Butkus 2015]). В связи с этим интерес представляют сведения о языках, на которых говорят литовцы. Согласно показателям Евробарометра 2012 года, по количеству языков, которыми владеют жители, Литва превышает средние показатели Европы: если среди европейцев еще одним языком, помимо родного, владеет $54 \%$ населения, в Литве - 92\%, двумя иностранными языками владеет $25 \%$ европейцев и $52 \%$ литовцев, тремя - $10 \%$ европейцев и $18 \%$ литовцев. Ни одним иностранным языком не владеет $46 \%$ европейцев и лишь $8 \%$ литовцев [Kiliulienè 2016].

Из иностранных языков доминирующим в Литве все еще остается русский (получивший официальный статус иностранного языка в середине 90-х годов XX в.) - им в той или иной мере владеет $63 \%$ населения. Польским языком владеет $8,5 \%$ населения Литвы, немецким - 8,3\%. Последняя перепись населения демонстрирует и существенное увеличение количества владеющих английским языком

1 Это в первую очередь татары, караимы, цыгане, немцы; далее украинцы, армяне и представители некоторых других этнических групп. 
по сравнению с 2001 г.: за десятилетие их прибавилось на 13,5 \%, так что к 2011 году в целом составляло 30,4\% населения страны [Lietuvos statistikos departamentas 2013a].

Граждане Литвы нередко называют родными два, а иногда и три языка. Среди жителей, считающих, что у них два родных языка, $56 \%$ называют комбинацию из литовского и русского, $19 \%$ литовского и польского, $14,4 \%$ - польского и русского, $2,1 \%$ - белорусского и русского, $1,6 \%$ - украинского и русского [Lietuvos statistikos departamentas 2013b].

В Литве основными этническими меньшинствами являются поляки $(5,61 \%)$ и русские $(4,78 \%)$. Родным языком считают свой этнический язык 99,2 \% литовцев, 87,2\% русских и 77,1 \% поляков [там же]. И хотя большую часть страны действительно можно назвать абсолютно литовской, степень этнической (не)однородности в разных регионах Литвы различна, на отдельных территориях преобладает польское или русское население.

Польскоязычным (до 77,8 \% населения) является восток и юговосток Литвы, но 24,4 \% жителей этих территорий считают русский язык одним из родных.

В Вильнюсе поляков - 16,5 \%, и $21 \%$ из них одним из родных языков называют русский (здесь и ниже приводятся данные двух крупных научных проектов (далее - Проекты) «Города и языки» и «Социолингвистическая карта Литвы», участницей которых была автор этой статьи. Результаты проектов обобщены в коллективных монографиях [Miestai ir kalbos 2010; Miestai ir kalbos II 2013]). Coгласно проектным данным, подавляющее большинство русского и русскоязычного населения сосредоточено в трех городах страны: в городе-порте Клайпеде (русских $21 \%$, а для $29 \%$ русский язык родной), Висагинасе, возникшем в 70-е годы прошлого века вместе с союзной атомной электростанцией (русских $52 \%$, русский язык родной - для $77 \%$ ), а также в столице, где этнические русские составляют около $12 \%$ населения, а жителей, считающих русский язык родным, - $27 \%$. Причем респонденты-поляки в Вильнюсе отмечают, что лучше, чем по-литовски и по-польски, говорят, пишут и читают по-русски, и только в понимании на слух этот язык уступает литовскому и польскому [Geben, Ramonienè 2015: 251]. Среди русских хорошо оценивают свое устное владение родным языком 95,1 \% участников опросов, умение хорошо читать - 98,4\%, 94,3 \% — хорошо писать по-русски [Gudavičienè 2010: 214]. 


\section{4. Социолингвистическая специфика Вильнюса}

Несмотря на то, что более половины жителей (63,6 \%) Вильнюса - литовцы, столица является самым многонациональным городом Литвы - в нем проживают представители 128 национальностей (из 154 всех этнических групп Литвы) [Lietuvos statistikos departamentas 2013b]. Однако социолингвистическая ситуация в Вильнюсе отличается от ситуации в других регионах Литвы не только количеством разноязычных жителей, но в первую очередь тем, что здесь на одной территории издавна регулярно используются, кроме государственного литовского, русский и польский языки. В транспорте, в школах, местах торговли, сфере обслуживания типичны постоянные кодовые переключения: можно услышать диалоги, включающие реплики на литовском и русском, русском и польском, а то и на всех трех языках.

Приведу иллюстрацию подобного кодового переключения в обыденной коммуникативной ситуации ${ }^{2}$ :

(1) Работница ателье по ремонту одежды завершает разговор с клиенткой-литовкой. В это время входит другая клиентка, здоровается по-русски. Обе женщины отвечают вошедшей по-русски, и работница продолжает разговор по-литовски:

- Rytoj apie trečia bus padaryta. Gerai? Galite ir vèliau užbègti, mes iki septyniu dirbam ('Завтра часам к трем будет готово. Хорошо? Можете и позже забежать, мы до семи работаем'). Далее обращается к русскоязычной клиентке:

- Ну, давайте посмотрим... Надо примерить. Вот сюда, пожалуйста.

Пока клиентка переодевается, работница отвечает на телефонный звонок, разговаривает по-польски, видимо, с кем-то из домашних:

— Tak, moge, tylko prędzej, jestem w pracy ... Gdzie?.. A, tak, zapomniałam. Tylko najpierw zjedz obiad, dobrze?... No to wszystko, wszystko ('Да, могу, только быстро, я же на работе... Куда?.. А, да, я забыла. Только пообедай перед этим, хорошо?.. Ну всё, всё').

И опять по-русски:

- Так... Ну-ка, покажитесь...

2 Записано 12.01.2018. 
Такое параллельное существование языков как в сознании индивидов, так и в общественном пространстве, имеет не только плюсы, но и минусы. В этом отношении весьма показательны материалы интернет-изданий и интернет-форумов, в которых затрагивается тема языков города ${ }^{3}$, а также фрагменты интервью с респондентами социолингвистических проектов.

Во-первых, давний языковой контакт и прямолинейно, некритично понимаемое коммуникативное удобство приводит к функционированию в Вильнюсе в той или иной степени искаженных вариантов всех трех языков. Так, польский язык Вильнюсского края, имеющий сходство с белорусским, в значительной степени отличается от польского стандарта, поэтому «настоящие» поляки легко распознают литовских поляков по их особому говору. По словам местной жительницы с университетским дипломом, полученным в Польше, именно этот неофициальный, нелитературный, столетиями формировавшийся в Вильнюсском крае язык дорог и близок полякам:

(2) Хотя в школе нам и старались привить настоящий польский язык, признаюсь, что большинство из нас, выйдя из школь, «упаковывали» этот язык в ранеи вместе с учебниками, а дома с близкими радостно щебетали на своем экзотическом «тутейшем» (букв. 'на здешнем') [delfi.lt/pilietis].

Русский язык Вильнюса также может вызывать нарекания не только у россиян, но и у грамотных носителей этого языка в самой Литве. Вот мнение жительницы исконно русскоязычного Висагинаса, переехавшей из России в Литву в 1988 г.:

(3) Р. ${ }^{4}$ Русский язык в Вильнюсе - он включает сочетания каких-то, не знаю, окончаний или ударений совершенно разных языков. Сльишу что-то польское, что-то белорусское, что-то еще от какого-то языка, т. е. чистого русского языка я в Вильнюсе, за двадцать с лишним лет проживания в Литве, не усльшала... Когда мне попадался на слух более-менее чистый язык - это были приезжие. На самом деле язык

${ }^{3}$ Сетевые материалы и цитаты из литовских работ приводятся в моем переводе.

${ }^{4}$ При цитировании фрагментов интервью используются следующие обозначения: И. — исследователь, Р. — респондент, в скобках после цитат указываются пол и возраст информанта. 
ужасный. Тем и отличается Висагинас, что здесь сохранен все-таки русский язык, изначально. 〈...〉 В Литве - не могу сказать за всю Литву, но в Вильнюсе - это точно не так [Ж., 45].

Жители Вильнюса и сами критически оценивают собственное знание родного языка и уровень владения русским языком своими русскоязычными согражданами:

(4) Р. Знание нескольких языков иногда допускает такую возможность, что в своей речи ты используешь разные языки, потому что просто... просто путаешься, или во всяком случае у меня такое бывает, и у многих моих друзей бывает. Это нормально, я считаю. Потому что это не так легко. Т. е. надо очень хорошо знать язык, надо быть специалистом в этом, надо быть склонным к филологии, я считаю, чтобы как бы углубиться в это и не делать таких вот ошибок. А если это как-то на жизненном уровне, я считаю, что это частые случаи. Я считаю, что это нормально [М., 21];

(5) Р. Ну, конечно, (говорим) уже с ошибками, и литовские слова появляются, какие-то местные ... местные наречия - польско-литовское, ударения ставятся неправильно... Люди, которые заканчивали русскую школу, они пишут уже с ошибками [Ж., 24].

Но и вильнюсский литовский язык, с его вкраплениями из русского и «тутейшего», также не считается образцовым для остальных регионов страны. Однако, как утверждают литовские социолингвисты, «несмотря на отрицательный официальный взгляд на столичную речь, жители Вильнюса лояльны к родному городу и даже в какой-то степени лингвоцентричны» [Keršytė 2014].

\section{5. Языковая повседневность Вильнюса в оценках жителей Литвы}

В последние годы одной из самых обсуждаемых интернет-комментаторами тем является «слышимость» и «видимость» русского и польского языков в общественном пространстве города. 
Вот примеры характерных интернет-шуток: Vilnius. Tai čia tas, kur pilna lenku ir visi kalba rusiškai? ('Вильнюс. Это там, где полно поляков и все говорят по-русски?'), Labas, ìstojau i Vilnių.. Gal žinai nebrangu lenku kalbos mokytoją? ('Привет, поступил [о вузе] в Вильнюс... Не знаешь ли недорого учителя польского языка?') [demotyvacija.1t].

Тема недоумения молодых людей, прибывающих на учебу в Вильнюс и сталкивающихся с непривычной для одноязычной Литвы языковой ситуацией, описывается и в следующей заметке о «простом мальчике», приехавшем учиться в Вильнюсский университет:

(6) ...Очень удивился герой истории, оказавшись на столичном вокзале, т. к. его окружали не только незнакомые люди, их «культурные» особенности, но и язык - не только мало ему известный, но и несколько отталкивающий из-за обстоятельств, хорошо усвоенных еще в школе. 〈...〉 Почему на автобусных остановках мне нужно объяснять, что я не говорю по-русски, а потом быстро соображать, где это я нахожусь, не в Калининграде ли. А может, скажете, что использование русского или польского языков есть норма в нашем обществе? 〈...〉 Простой пример: в парижском метро подойдите к франиузу и по-литовски спросите его о чем-нибудь. Не стоит даже фантазировать, что будет дальше, т. к. уважаюший себя, образованный и культурный человек так бы вообще не поступил. Даже турист. А вот гражданин Литвы (!) Иван, 16 лет живущий в Литве, как ни в чем не бывало обрашается к другим по-русски. В иелях соблюдения его интересов в Вильнюсской мэрии при приеме на работу требуют владения русским и польским языками. 〈... В Литве, наверное, самое большое в мире количество польских школ, кроме того, Министерство образования Литвы издало польских учебников больше, чем любая другая страна, кроме самой Польши [pilietis.delfi.lt/ voxpopuli].

К заметке было дано 94 комментария. Больше половины комментаторов солидарны с автором истории: использование языков национальных меньшинств в общественных местах (в магазинах, на вокзале, в транспорте) не отвечает нормам «правильного» поведения, там должен звучать государственный язык. Но было и немало 
реплик, апеллирующих к традиции сосуществования нескольких языков в Литве, напр.:

(7) Друг, это Литва. В ней живут и поляки, и русские, еще и евреи когда-то жили... Литва разная, в ней существуют разные языки и народы. Я литовеи, но знаю и русский, и польский. Со всеми, кто не говорит по-литовски, общзаюсь на их языке. Не думаю, что я меньше литовеи, чем ты. Учи русский и польский, умнее будешь. 〈...〉 Если не спится по ночам и мучает вопрос, почему в Литве немало людей говорят по-русски и по-польски, - открой учебник истории для начальных классов. В Вильнюсе до Второй мировой войны было почти $36 \%$ русских, столько же поляков, ещче около $15 \%$ евреев (очень «литовский» город - исторически), остальные - несколько прочентов - литовиь ... [там же].

Участники наших социолингвистических исследований также рассказывали о ситуациях, когда использование русского языка вне дома вызывало необъяснимую, с их точки зрения, реакцию со стороны окружающих, напр.:

(8) Вот я недавно познакомилась и понятно, что я говорю по-русски, и мне задают вопрос: «А откуда вы приехали?» Я говорю: «Я ниоткуда не приехала, я родилась здесь». И я сразу начинаю говорить, что мои родители родились здесь. И не надо думать, что если человек говорит по-русски, то он откудато приехал. Я считаю, что это какая-то ограниченность сознания. Вообще, незнание собственной истории. 〈...〉 Меня очень возмутило, когда я прошлым летом слушала по радио интервью с одним парламентарием... Он сказал, что заметил такую тенденцию, что теперь русские стали свободнее друг с другом разговаривать по-русски, что он стал чаще сльшать русскую речь. Вот, говорит: «Я сльшиу, в магазине разговаривают по-русски. Думаю, приезжие. А потом подходят $\kappa$ кассе, начинают говорить по-литовски. Значит, местные. Ну, раньше они тише говорили... Так как это понять? Значит, мы для них как литовцы уже больше не котируемся?» То есть меня вообще возмутил... ход мысли! То есть что, мы должны бояться того, что мы не литовцы? Мой вывод совсем другой: это показатель того, что мы - граждане Евросоюза. 
Вступив в Евросоюз, национальные меньшинства стали чувствовать себя более полноченными и более защищенными. И, в общем, многие вещи, которые раньще могли позволить себе сказать некоторые товарищи, они уже не говорят. Я считаю, что если бы кто-то из Евросоюза усльшал вот такие рассуждения, это был бы просто скандал. Потому что, ну, это просто возмутительно [Ж., 46].

Еще одна интернет-дискуссия была вызвана заметкой «Врач: почему в независимой Литве меня насилуют, заставляя говорить по-русски?» о враче из Каунаса (всегда являвшегося самым «литовским» городом страны и по этническому составу, и по духу), несколько лет назад переехавшей в Вильнюс и начавшей работать в одной из поликлиник:

(9) ...Женшина нигде не слышала так много русского языка, как в столице. У нее сложилось мнение, что в Вильнюсе либо нет литовиев, либо они не болеют. 〈...〉 Некоторым она предлагает поехать к врачу в Испанию и посмотреть, на каком языке он будет говорить.

Врача удивляет и поведение пациентов-поляков, которые стремятся общаться с медиками по-русски: Если скажешь им, что не станешь говорить по-русски, они огрызаются - «тогда будем говорить по-польски» [1rt.lt/naujienos/lietuvoje].

Анализ мнений жителей Литвы относительно их языкового существования показывает, что наряду с литовским, приемлемым для общения многими считается только один язык, ср.:

(10) Государственный язык - литовский, международный язык английский. Пожалуйста, на этих языках давайте и будем общзаться в Литве [ve.lt/naujienos].

При этом к 2010 году, по данным социолингвистических опросов, лишь $1 \%$ жителей Вильнюса были моноязычными, у $10 \%$ два родных языка, 34 \% владели тремя языками, $41 \%$ - четырьмя [Gudavičienè 2010: 217], и русский в числе этих языков обязательно присутствует.

Вообще, тема языков общения в медицинских учреждениях (впрочем, как и в других государственных учреждениях, куда обращается много людей старшего возраста, не владеющих литовским 
языком в достаточной степени) в настоящее время очень актуальна для Вильнюса. В 2657 разнообразных по тону комментариях преобладали советы «не потакать», «игнорировать», «отстаивать свое право пользоваться только государственным языком», а с другой стороны, «не делать из этого проблемы и говорить так, чтобы всем было удобно», «учитывать специфику столицы или вернуться в чисто литовский город», «понять, что это Вильнюс» и т. п.

Столкновение крайних мнений хорошо иллюстрирует дискуссия, вызванная заметкой «До чего мы докатились? Мой ребенок стесняется во дворе общаться с русскими»:

(11) ...Мне стылдо, что мы живем в русофобском государстве. Стылдно, что встречаем по начиональности. Стылдн, что в свободной и демократической стране человек не может в магазине, на улице со своими говорить на своем родном языке... [bendraukime.lrytas.lt/man-rupi].

Мнения более чем 1000 комментаторов разделились почти поровну. Одни утверждают:

(12) Если ребенок стыдится русского языка, это естественно, значит, хороший ребенок, еще не испорченный, и мама должна гордиться, что у ребенка есть совесть - в отличие от большинства взрослых русских. Стылно быть русским в наше время [там же].

Но в комментариях выражается и другое мнение:

(13) Не учу своих детей ненависти ни к какому народу или языку. Учу, чтобь были и оставались Людьми. 〈... Если мы будем учить детей ненависти, они и станут распространять ненависть. Глаз за глаз, и весь мир ослепнет... [там же].

В целом на основании анализа собранных интернет-комментариев можно сделать вывод, что самое существенное влияние на мнения комментаторов по поводу использования русского и польского языков в Литве оказывает историческая память и нынешние межгосударственные отношения.

Кроме того, в негативных высказываниях приезжих из этнически однородной части Литвы очевидно недостаточное понимание специфики языковой ситуации в Вильнюсе и некоторых других регионах, где живет значительное количество носителей русского 
и польского языков (об этом см. [Лихачева 2014а, 2014в]). В столице, туристических местах и курортных городах Литвы владение русским языком действительно требуется при устройстве на работу, особенно в сферу обслуживания, поскольку здесь регулярно бывают гости из России и тех стран, в которых русский язык продолжает восприниматься как язык межнационального общения, и потому приезжие рассчитывают на возможность его использования в большей степени, чем английский, который в сознании многих еще не является на этих территориях реальным лингва франка 5 .

(14) Я изучаю русский язык, - пишет в блоге слушателей языковых курсов молодой человек, - потому что он везде нужен. Может, в других городах и не очень, но здесь, в столице, если хочешь устрочться на работу, русский язык так же важен, как английский [mokslonamai.lt/blogas].

Очень показательно мнение относительно сосуществования языков в столице Литвы моего коллеги по университету, известного литуаниста Антанаса Сметоны, живущего в Вильнюсе с середины 70-х годов минувшего века:

(15) Вильнюсеи - это переехавщий либо из деревни, либо из Каунаса. К последним принадлежу и я. 〈...〉 Сколько людей и народов здесь всё создавали. Вильнюс не является литовским городом в привычном для нас национальном понимании. Поляки, евреи, русские и приглашенные мастера смогли здесь вместе жить и творить. 〈...〉 Помню, однажды нас, студентов, отправили приводить в порядок Ужупис (район в старой части города. - А. Л.). Нами руководила одна женщина, русская. $\mathrm{Mbl}$ насмехались над ней, над тем, что она говорит с нами по-русски, а женщина взяла и заплакала. Она нам говорит: я литовка, я только по-литовски разговаривать не умею. Тогда, скорее всего, и началось понимание того, кто есть житель Вильнюса. Это было для меня уроком, который я помню до сих пор... [web. vu.lt/flf].

5 Лингва франка здесь понимается так же, как в [Павленко 2016: 31]: «язык, используемый как средство межэтнического общения в определённой сфере деятельности». 
В 2016 году в Вильнюсе параллельно с литовскими названиями Русской (Rusu gatvè) и Польской улиц (Lenku gatvè) были вывешены таблички на языках этих народов, что вызвало бурные споры в интернет-пространстве. Наряду с резким осуждением такой инициативы городских властей высказывалась и ее поддержка, возникали конструктивные - вполне вильнюсские - предложения, например:

(16) Думаю, что суть не в табличках на других языках. Кому они мешают?! А вот нашу литовскую толерантность к культуре других народов действительно демонстрируют. Не согласился бы только с одним: чтобы рядом с надписями на государственном языке вывешивались таблички только на русском или только на польском языках. Вильнюс - многонациональный город, поэтому должны быть надписи и на белорусском, и на идише, и на татарском, и на караимском [respublika.lt/lt/ naujienos].

\section{6. Обобщение}

На фоне непрекращающейся эмиграции, в связи с чем эксперты говорят о серьезных угрозах жизнеспособности страны, население столицы увеличивается в первую очередь за счет внутренней миграции, в результате чего по количеству молодых работоспособных жителей Вильнюс не уступает столицам скандинавских стран, а на фоне столиц соседних Балтийских государств выглядит лучше [8 pavojingos Lietuvos demografijos tendencijos]. Но, как ни парадоксально, в результате этого сегодняшняя демографическая, а с ней и языковая картина Вильнюса стремительно меняется: город становится все более литовским. Очевидно, не все новые жители столицы готовы принять и понять истоки коммуникативной специфики Вильнюса. Складывающаяся ситуация требует изучения и, возможно, коррекции языковой политики государства. Не изучены и установки литовского общества относительно новых языков, которые могут звучать в городах Литвы.

Такие исследования особенно важны сейчас, когда ученые заговорили о том, что образование на карте Европы новых государств сопровождается в них «лингвистическим национализмом», «лингвистической гомогенизацией общества - предоставлением языку 
и культуре большинства государственной монополии, дискриминацией региональных языков и языков национальных меньшинств» [Tamaševičius 2011: 145].

Перефразируя мысль социолога-урбаниста Шарон Зукин о том, что те, «кто ун ас ле д о в а л город (разрядка моя. - $A$. Л.), предъявляют свои права на его центральные символические пространства» [Зукин 2015: 74], можно отметить: по этой же причине наследниками города могут предъявляться права на языковое наполнение городских пространств. В сегодняшнем Вильнюсе так и происходит: период после восстановления независимости Литвы в 1991 г., когда русский и польский были малозаметны в общественном пространстве и использовались в основном как домашние языки для общения в кругу семьи, сменился естественными переходами с одного языка на другой в зависимости от коммуникативной необходимости, потому что «дом» - это не только семья, но и город в целом. Возможной причиной этого служит не столько прямое поощрение со стороны титульной нации, сколько неоправданно широкое присутствие английского языка во многих сферах жизни, что вызывает недоумение даже у многих литовцев.

Как пишет Лаймонас Бриедис, автор книги «Вильнюс: свой и чужой», у Вильнюса всегда была больше чем одна идентичность, что символизирует полифония его имени: еврейское Vilne, польское Wilno, русское Vilna, немецкое Wilna, белорусское Vilno и литовское Vilnius. С каждым из названий города связан свой дух Вильнюса, свои воспоминания, своя колея судьбы [Briedis 2015].

Сложная и переменчивая историческая судьба Вильнюса имеет прямое продолжение в сегодняшней жизни города: в его нынешнем облике, официальной и неофициальной топонимике, этнической неоднородности, проявлениях лингвистического национализма и одновременно - в привычной языковой полифонии.

Сохранение собственного культурно-языкового разнообразия на фоне давления глобализации, увеличение числа иностранных фирм, рост туристических потоков с Запада и Востока, интенсивная университетская жизнь с растущим академическим обменом все эти факторы сегодня формируют пеструю культурно-языковую жизнь столицы Литвы в значительно большей степени, чем на других территориях страны. И хотя в литовском обществе существует противоречивое отношение к исторически сформировавшемуся вильнюсскому литовско-польско-русскому многоязычию, 
одновременно заметно и стремление к укреплению репутации современного толерантного мультикультурного и многоязычного столичного города.

\section{Литература}

Бразаускене, Лихачева 2011 - Е. Бразаускене, А. Лихачева. Русские в современной Литве: языковые практики и самоидентификация // Диаспоры. № 1. М.: Астрель, 2011. С. 61-85. [Je. Brazauskienè, A. Lichačiova. Russkie v sovremennoi Litve: iazykovyje praktiki i samoidentifikatsiya [Russians in contemporary Lithuania: Linguistic practices and self-identification]. Diaspory [Diasporas]. No. 1. Moscow: Astrel', 2011. Р. 61-85].

Брайт 1975 - У. Брайт. Введение: параметры социолингвистики. Пер. с англ. // Новое в лингвистике. Вып. VII. М.: Прогресс, 1975. С. $34-$ 41. [U. Brait. Vvedenie: parametry sotsiolingvistiki [W. Bright. Introduction: The dimensions of sociolinguistics] // Novoe v lingvistike, Issue VII. Moscow: Progress. 1975. P. 34-41].

Вахтин, Головко 2004 - Н. Б. Вахтин, Е. В. Головко. Социолингвистика и социология языка. СПб.: Гуманитарная академия: Европейский университет в Санкт-Петербурге, 2004. [N. B. Vakhtin, E. V. Golovko. Sotsiolingvistika i sotsiologiia iazyka. [Sociolinguistics and Sociology of Language]. Saint Petersburg: Humanitarian Academy: European University at St. Petersburg, 2004].

Венцлова 2012 - Т. Венцлова. Вильнюс: город в Европе. Пер. с лит. СПб.: Издательство Ивана Лимбаха, 2012. [T. Ventslova. Vil'nyus: gorod v Evrope. [Vilnius - a city in Europe]. Saint Petersburg: Ivan Limbakh Publishing House, 2012].

Зукин 2015 - Ш. Зукин. Культуры городов. Пер. с англ. М.: Новое литературное обозрение, 2015. [Sh. Zukin. Kul'tury gorodov [The cultures of cities]. Moscow: New Literary Observer, 2015].

Лихачева 2015 - А. Лихачева. Образ родного языка в высказываниях русскоязычных жителей Литвы // Русский язык за рубежом. 2015. № 4 (251). М.: Отраслевые медиа. С. 40-45. [A. Lichačiova. Obraz rodnogo iazyka v vyskazyvaniyakh russkoiazychnykh zhitelei Litvy [Image of the Native Language in the Utterances of Russian-Speaking Citizens of Lithuania]. Russian language abroad. 2015. No. 4 (251). Moscow: Otraslevye media. P. 40-45].

Лихачева 2014a - А. Лихачева. Чужое мнение и взаимоотношения русскоязычных жителей Литвы с родным языком // Коммуникативные исследования. № 2. Омск: Омский государственный университет 
им. Ф. М. Достоевского. 2014. № 2. С. 40-49. [A. Lichačiova. Chuzhoe mnenie i vzaimootnosheniia russkoiazychnych zhitelei Litvy s rodnym iazykom [The outside opinion and the attitudes of the Russian-speaking citizens of Lithuania towards their native language]. Communicative Studies. Omsk: Omsk State University named after F. M. Dostoevsky, 2014, No. 2. P. 40-49].

Лихачева 2014в - А. Лихачева. Взаимодействие языков и народная социолингвистика: опыт Литвы // Т. Солдатенкова и Л. Шипелевич (ред.). Człowiek. Świadomość. Komunikacja. Internet. Левен - Варшава: Левенский католический университет, Варшавский университет, 2014. C. 1105-1118. [A. Lichačiova. Vzaimodeistvie iazykov i narodnaia sotsiolingvistika: opyt Litvy. [Interaction of languages and folk sociolinguistics: the experience of Lithuania] // T. Soldatenkova. L. Szypielewicz (eds.). Man. Consciousness. Communication. Internet. Leuven - Warsaw: Catholic University of Leuven, University of Warsaw, 2014. P. 1105-1118].

Павленко 2016 - А. Павленко. Русский язык как лингва франка в зарубежной сфере обслуживания // Мир русского слова. № 1. СПб.: РОПРЯЛ, 2016. С. 23-32. [A. Pavlenko. Russkii iazyk kak lingva franka $\mathrm{v}$ zarubezhnoi sfere obsluzhivaniia [Russian as a Lingua Franca in the Global Service Industry]. The World of Russian Word. No. 1. Saint Petersburg: ROPRYAL, 2016. P. 23-32].

Allard, Landry 1992 - R. Allard, R. Landry. Ethnolinguistic Vitality Beliefs and Language Maintenance and Loss // W. Fase, K. Jaspaert and S. Kroon (eds.). Maintenance and Loss of Minority Languages. Amsterdam: John Benjamins Publishing Company, 1992. P. 171-196.

Bourdieu 1991 - P. Bourdieu. Language \& Symbolic Power. J. B. Thompson (ed.). Cambridge: Polity Press, 1991.

Briedis 2015 - L. Briedis. Vilnius: savas ir svetimas. [Vilnius. City of Strangers]. Vilnius: Baltos lankos, 2015.

Butkus 2015 - A. Butkus. Lietuvos gyventojai tautybès požiūriu. [People of Lithuania by nationality], 2015. Retrieved from http://alkas. 1t/2015/12/16/a-butkus-lietuvos-gyventojai-tautybes-poziuriu/.

Geben, Ramonienè 2015 - K. Geben, M. Ramonienè. Language use and self-identification: The case of Lithuanian Poles // Sociolinguistic Study. Vol. 9.2-3. P. 243-267. Equinox Publishing. 2015. DOI: 10.1558/sols. v9i2.26387.

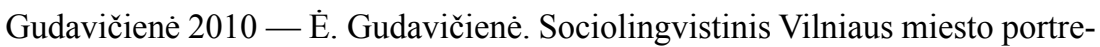
tas // M. Ramonienè (red.). Miestai ir kalbos. [E். Gudavičienè. A sociolinguistic portrait of Vilnius // M. Ramonienè (ed.). Cities and languages]. Vilnius: Vilnius University, 2010. P. 207-229].

Keršytė 2014 - A. Keršytė. Vilniaus kalba — vilnietiškos tapatybès dalis. [Vilnius language - part of the identity of Vilnius residents], 2014. Retrieved from http://sociologai.lt/2014/vilniaus-kalba-vilnietiskos-tapatybes-dalis/. 
Kiliulienè 2016 - J. Kiliulienè. Lietuvių daugiakalbystė — tarp anglų ir rusų [Multilingualism of Lithuanians - between English and Russian], 2016. Retrieved from http://www.veidas.lt/lietuviu-daugiakalbyste-\%E2\%80\%93tarp-anglu-ir-rusu.

Lietuvos statistikos departamentas 2013a - Gyventojai pagal išsilavinimą ir kalbų mokejimą [Population by education and language skills: Results of the 2011 Population and Housing Census, Republic of Lithuania], 2013. Retrieved from https://osp.stat.gov.lt/documents/10180/217110/ Gyv+pagal+i\%C5\%A1silavinima_ir_kalbu_mokejima.pdf/b75c5e7ae733-48fa-95e4-83d485c6726a.

Lietuvos statistikos departamentas $2013 \mathrm{~b}$ - Gyventojai pagal tautybę, gimtąją kalbą ir tikybą [Ethnic composition of the population, mother tongue and religion: Results of the 2011 Population and Housing Census, Republic of Lithuania],2013. Retrieved from https://osp.stat.gov.lt/documents/10180/217110/Gyv_kalba_tikyba.pdf/1d9dac9a-3d45-4798-93f5$941 \mathrm{fed} 00503 \mathrm{f}$.

Lichačiova 2013 - A. Lichačiova. Visagino sociolingvistinė specifika ir perspektyvos // M. Ramonienè (red.). Miestai ir kalbos II. Sociolingvistinis Lietuvos žemèlapis. [A. Lichačiova. Sociolinguistic specificity and potential of Visaginas // M. Ramonienè (ed.). Cities and languages II. A sociolinguistic map of Lithuania]. Vilnius: Vilnius University, 2013. P. $185-216$.

Lichačiova 2010 - A. Lichačiova. Vilniaus ir Klaipèdos rusų ir rusakalbių tapatybės savivokos ypatumai // M. Ramonienè (red.). Miestai ir kalbos. [A. Lichačiova. Self-identification of the Russian and Russian-speaking population of Vilnius and Klaipeda // M. Ramonienè (ed.). Cities and languages]. Vilnius: Vilnius University, 2010. P. 125-151.

Lichačiova, Markova 2014 - A. Lichačiova, S. Markova. Dovanota vertybė ar ịsiūlytas paveldas? Lietuvos rusakalbių nuostatos gimtosios kalbos atžvilgiu // Taikomoji kalbotyra. [Endowed Value or Imposed Heritage? Attitudes of Russian-Speaking Lithuanian Citizens towards Their Native Language // Applied Linguistics]. No. 4. Vilnius: Vilnius University, 2014. Retrieved from https://taikomojikalbotyra.1t/ojs3/index.php/taikomoji-kalbotyra/article/view/34/29.

Miestai ir kalbos 2010 - M. Ramonienè (red.). Miestai ir kalbos. [M. Ramonienè (ed.). Cities and languages]. Vilnius: Vilnius University, 2010.

Miestai ir kalbos II 2013 - M. Ramonienè (red.). Miestai ir kalbos II. Sociolingvistinis Lietuvos žemèlapis. [M. Ramonienè (ed.). Cities and languages II. A sociolinguistic map of Lithuania]. Vilnius: Vilnius University, 2013.

Stravinskienè 2013 - V. Stravinskienè. Migraciniai procesai ir etninė demografinè Vilniaus padètis: XX a. 3-4 dešimtmečiai // OIKOS: Lietuvių migracijos ir diasporos studijos. [Migratory processes and the 
ethno-demographic situation in Vilnius in the 1920s and 1930s // OIKOS: Lithuanian migration and diasporas studies]. No. 2 (16). Vilnius: Versus aureus, 2013. P. 17-29.

Tamaševičius 2011 — G. Tamaševičius. Tauta, gimusi iš filologijos, ir lingvistinio nacionalizmo fenomenas // Darbai ir dienos [A nation imerged from philology and the phenomenon of linguistic nationalism // Deeds and Days]. No. 56. Kaunas: Vytautas Magnus University, 2011. P. 142-153. 8 pavojingos Lietuvos demografijos tendencijos - $[8$ dangerous trends of the Lithuanian demography], 2015. Retrieved from http://www.veidas. lt/8-pavojingos-lietuvos-demografijos-tendencijos/.

Vilniaus tautos - [Ethnic groups of Vilnius]. Retrieved from http://www.quest. lt/po-lietuva/nacionaline-ideja-po-lietuva/6803/vilniaus-tautos/.

\section{Источники}

bendraukime.lrytas.lt/man-rupi - A. Jurgel. Kur nusiritome? Mano vaikas gedijasi kieme bendrauti su rusais [What we have come down to? In a yard, my child is ashamed of communication with Russians], 2014. Retrieved from http://bendraukime.lrytas.lt/man-rupi/kur-nusiritome-mano-vaikas-gedijasi-kieme-bendrauti-su-rusais.htm\#.U9OrOkA9ZCQ.

delfi.lt/pilietis - Mes - Vilniaus lenkai: neiprasta tradicinio lenko ausiai kalba, skardus juokas, gan ryški apranga [Vilnius Poles: language unusual for the ear of a traditional Pole, loud laughter, bright clothes], 2014. Retrieved from https://www.delfi.lt/pilietis/voxpopuli/mes-vilniaus-lenkai-neiprasta-tradicinio-lenko-ausiai-kalba-skardus-juokas-gan-ryski-apranga.d?id $=63871718$.

demotyvacija.lt - https://demotyvacijos.tv3.1t/.

lrt.lt/naujienos/lietuvoje - M. Jackevičius. Gydytoja: kodèl nepriklausomoje Lietuvoje esu prievartaujama kalbèti rusiškai? [Doctor: why do they force me to speak Russian in independent Lithuania?], 2013. Retrieved from http://www.lrt.lt/naujienos/lietuvoje/2/25414/gydytoja-kodel-nepriklausomoje-lietuvoje-esu-prievartaujama-kalbeti-rusiskai.

mokslonamai.lt/blogas - Kalbų kursai „Mokslo Namai” [Language courses "House of Science"], 2013. Retrieved from http://www.mokslonamai.lt/ blogas/kinunorveguogalvokieciukokiakalbamokytismokslonamukolektyvoirstudentunuomones.

pilietis.delfi.lt/voxpopuli - Apie rusų ir lenkų kalbas: kodèl aš turiu jas mokèti?

[On the Russian and Polish languages, why should I speak them?], 2012. Retrieved from http://pilietis.delfi.lt/voxpopuli/apie-rusu-ir-lenku-kalbaskodel-as-turiu-jas-moketi.d?id=59549167.

respublika.lt/lt/naujienos — Jei kabini ne valstybine kalba parašytą lentelę, numatyk ir pasipiktinimą [If you hang a table written in a non-state language, 
anticipate an outrage], 2016. Retrieved from http://www.respublika.lt/lt/ naujienos/lietuva/lietuvos_politika/jei_kabini_ne_valstybine_kalba_parasyta_lentele_numatyk_ir_pasipiktinima/.

ve.lt/naujienos - Kreiptis lietuviškai arba nešdintis ị Rusiją [To appeal in Lithuanian or to get to Russia], 2011. Retrieved from http://www.ve.lt/ naujienos/lietuva/vakaru-lietuva/kreiptis-lietuviskai-arba-nesdintis-irusija-657410/komentarai/,page. 15 .

web.vu.lt/flf - L. Mustafinaitè. Garsų lituanistą A. Smetoną Vilnius išmoke pakantumo [The well-known specialist in Lithuanian philology A. Smetona Vilnius taught tolerance]. 2008. Retrieved from http://web.vu.lt/flf/a. smetona/wp-content/uploads/Pop_Pakantumas.pdf. 